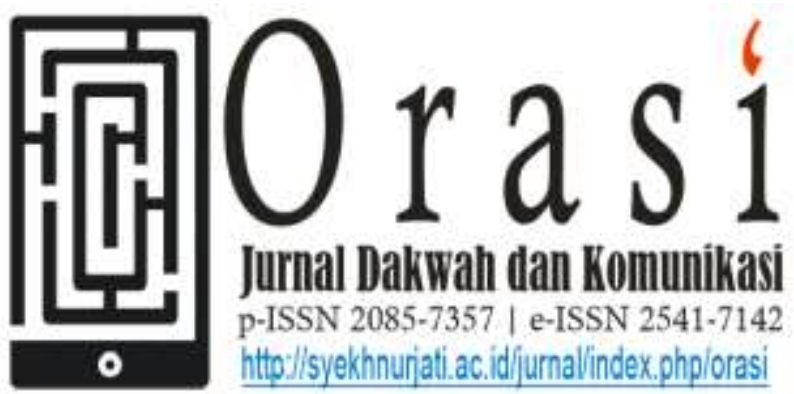

Volume 12 No. 1 Juli 2021

\title{
PROMOSI PRODUK DI ERA DIGITALISASI TERHADAP MINAT MASYARAKAT BERUMRAH PADA BIRO HAJAR ASWAD MUBAROQ SURAKARTA
}

\section{PROMOTION OF PRODUCTS IN THE AGE OF DIGITALIZATION TOWARDS THE INTEREST OF UMRAH AT HAJAR ASWAD MUBAROQ BUREAU IN SURAKARTA}

\author{
Kristy Andriyani ${ }^{1}$, Ade Yuliar ${ }^{2}$, Muhammad Raqib ${ }^{3}$ \\ ${ }^{1}$ Program Studi Manajemen Dakwah, IAIN Surakarta \\ Jl. Pandawa No.5, Kartasura, Sukoharjo \\ e-mail: ${ }^{\text {a) } k r i s t y a n d r i @ g m a i l . c o m, ~}$ \\ b)adeyuliar2107@gmail.com, \\ ${ }^{c)}$ raqib.muhammad@gmail.com
}

\begin{abstract}
ABSTRAK
Di era digitalisasi ini penggunaan sosial media yang berkembang sangat pesat memudahkan setiap orang dapat berkomunikasi dimana saja tanpa batasan tempat dan waktu. Berbagai sosial media seperti instagram, facebook, whatssApp selain sebagai media komunikasi dapat dimanfaatkan sebagai media promosi. Banyak kalangan usaha seperti pada biro umrah dengan cara memanfaatkan sosial media untuk promosi produk dan jasa dengan membuat promosi yang kreatif dan unik. Karena dengan adanya sosial media di era digitalisasi ini komunikasi jauh lebih mudah dan dapat dijangkau dengan cepat oleh seluruh masyarakat. Penelitian ini bertujuan untuk mengetahui dan menganalisis pengaruh promosi produk di era digitalisasi terhadap minat masyarakat untuk umrah di Biro Hajar Aswad Mubaroq Surakarta. Penelitian ini menggunakan metode penelitian kuantitatif. Sampel penelitian adalah jamaah Biro Hajar Aswad Mubaroq Surakarta yang telah menggunakan jasa produk umrah. Penelitian ini menggunakan data primer berupa angket dan teknik pengambilan sampel menggunakan metode non probability sampling. Hasil penelitian menunjukkan bahwa promosi produk di era digitalisasi berpengaruh positif dan signifikan terhadap minat masyarakat untuk umrah di Biro Hajar Aswad Mubaroq Surakarta. Dapat dilihat dari hasil analisis yang
\end{abstract}


menunjukkan nilai t hitung $11,363>\mathrm{t}$ tabel 1,658 dan nilai signifikansi sebesar $0,000<0,05$.

Kata Kunci: Promosi Produk, Digitalisasi, Minat Masyarakat

\section{ABSTRACT}

In this era of digitalization, the use of social media is growing very rapidly, making it easier for everyone to communicate anywhere without limitation of place and time. Various social media such as Instagram, Facebook, and WhatsApp, apart from being communication media, can be used as promotional media. Many businesses, such as the umrah bureau, use social media to promote products and services by making creative and unique promotions. Because of the existence of social media in this digitalization era, communication is much easier and can be reached quickly by the whole community. This study aims to determine and analyze the effect of product promotion in the digitalization era on public interest in Umrah at Hajar Aswad Mubaroq Bureau in Surakarta. This study used quantitative research methods. The research sample was the pilgrims of Hajar Aswad Mubaroq Surakarta Bureau who had used the services of Umrah products. This study used primary data in the form of a questionnaire and non-probability sampling technique. The results show that product promotion in the digitalization era has a positive and significant effect on public interest in Umrah at Hajar Aswad Mubaroq Bureau in Surakarta. It can be seen from the result of the analysis which shows the $t$ value of $11,363>t$ table 1,658 and the significance value of $0,000<0,05$.

Keywords: Product Promotion, Digitalization, Public Interest.

\section{Pendahuluan}

Persaingan usaha yang semakin ketat dalam hal ekonomi digital sudah semakin meningkat dengan adanya perkembangan teknologi informasi. Oleh karena itu terlebih bagi para pengusaha ekonomi kreatif harus memperhatikan fenomena tersebut. Para pengusaha mengetahui dan menguasai digital marketing yang berhubungan dengan ekonomi digital (Sholihin et al., 2018).Salah satunya bisnis yang memerlukan marketing digital seperti bisnis biro atau travel haji umrah. Fokus kegiatan promosi adalah menawarkan suatu usaha yang dalam mengkomunikasikan manfaat dari suatu produk tersebut dan mengajak pelanggan dan semua orang untuk membeli produk tersebut (Kotler \& Armstrong, 2012).

Saat ini kemajuan dalam ekonomi digital seperti penggunaan sosial media dalam penyampaian informasi produk memberikan peluang pasar, terlebih segmen generasi milenial tentunya update dengan akun sosial media. Sehingga hampir di setiap waktu dan tempat kini banyak orang sudah terakses dengan sosial media karena kebutuhan komunikasi dan informasi. Dimulai dari media sosial seperti facebook, twitter, instagram, maupun sosial media lainnya (Sholihin et al., 2018). Periklanan yang berbasis digital menjadi trend di era internet, para pemilik merek mulai menjadikan media digital sebagai promosi dan pemasaran yang baru. Media 
sosial telah mengubah bagaimana konsumen berinteraksi dan bagaimana perusahaan memasarkan produk sebagai peluang usaha yang siap dipasarkan dan dijual (Safira, 2018). Strategi promosi penjualan era digital dengan media sosial sangat lebih menarik dan banyak diminati peerkembangan jaman dan trend masyarakat saat ini mereka lebih sering menggunakan media internet. Keberadaan sosial media juga menjadi peluang baru bagi perusahaan besar sebagai salah satu strategi pemasaran mereka. Keuntungan dari influencer pemasaran yaitu menciptakan kecenderungan untuk membeli lebih banyak produk (Lynna, 2019).

Tantangan bagi pelaku bisnis seperti biro atau travel haji dan umrah saat ini yaitu mengoptimalkan kegiatan strategi promosi produk mereka. Banyak media promosi produk yang digunakan untuk melakukan promosi salah satunya dengan media sosial. Kaitannya dengan promosi produk era digitalisasi yaitu dimana kegiatan yang dapat dilakukan seperti biro atau travel umrah untuk meningkatkan penjualan serta minat masyarakat untuk umrah dengan media digital ini. Banyak cara yang dilakukan agar meningkatkan jumlah minat masyarakat seperti meningkatkan jumlah jamaah umrah pada sebuah biro yaitu dengan membuat promosi pada sosial media yang kreatif dan menarik.

Biro Hajar Aswad Mubaroq Surakarta merupakan salah satu biro umrah di Surakarta. Biro Hajar Aswad Mubaroq merupakan pelopor biro perjalanan umrah yang berbasis Solo dan Semarang. Biro Hajar Aswad Mubaroq berdiri pada 17 Agustus 2012 yang menyediakan paket perjalanan umrah, haji plus, dan paket tour ke luar negeri. Biro Hajar Aswad Mubaroq Surakarta merupakan biro yang salah satunya juga melakukan promosi produk digital menggunakan sosial media dalam meningkatkan penjualan paket produk jasa umrah mereka. Promosi produk yang dilakukan salah satunya yang mereka gunakan melalui sosial media yaitu dengan menggunakan instagram, facebook, dan whatsApp. Dengan adanya whatsApp disini untuk menginformasikan kembali kepada calon jamaah yang sekiranya menghubungi dan tertarik dengan produk yang ditawarkan melalui kedua sosial media tadi (Fajar, 2019).

Tabel 1. Jumlah Kegiatan Marketing Pada Sosial Media di Biro Hajar Aswad

\begin{tabular}{cc}
\hline Media & $\begin{array}{c}\text { Jumlah } \\
\text { ( Januari 2020 ) }\end{array}$ \\
\hline Instagram & 32 Postingan \\
\hline Facebook & 17 Postingan \\
\hline WhatsApp & 620 Postingan
\end{tabular}

Sumber : Data diolah, per Januari 2020

Terlihat dari tabel di atas menunjukkan bahwa hasil jumlah kegiatan marketing selama periode januari 2020 di Biro Hajar Aswad Mubaroq Surakarta. Marketing pada sosial media yang paling sering digunakan adalah pada whatsApp. Melalui media perantara ini disebabkan karena semua promosi yang dilakukan baik secara konvensional maupun digital akan berakhir pada media whatsApp ini dalam berkomunikaasi dengan customer. WhatsApp lebih mudah dijangkau semua kalangan 
masyarakat serta lebih mudah untuk digunakan (Fajar, 2019). Diharapkan dengan promosi melalui media tersebut menimbulkan nilai dari masyarakat. Nilai tersebut seperti hasrat, minat, ketertarikan, perhatian terhadap produk jasa yang dipromosikan. Dapat juga mendorong konsumen tersebut melalui promosi di sosial media di era digitalisasi ini.

Konteks e-marketing merupakan suatu usaha perusahaan untuk menyampaikan suatu informasi, berkomunikasi, melakukan promosi serta menjual produk dan jasa menggunakan internet (Kotler \& Keller, 2008). E-marketing merupakan penggunaan sumber media elektronik sebagai media utama dalam pemasaran, misalnya menggunakan internet. Salah satu bentuk pemasaran saat ini yang menunjukkan perkembangan sangat pesat bagi suatu perusahaan yaitu e-marketing (electronic marketing atau pemasaran elektronik) (Kotler \& Keller, 2012). Tentunya strategi marketing bisnis biro perjalanan umrah dalam hal ini menguji apakah dengan penggunaan media sosial berpengaruh pada minat untuk melaksanakan ibadah umrah.

\section{Landasan Teoritik}

\subsection{Promosi Produk}

Menurut Kotler Keller dalam (Lancarya, 2016) salah satu bentuk pemasaran saat ini yang menunjukkan perkembangan pesat yaitu e-marketing (electronic marketing atau pemasaran elektronik). E-marketing merupakan suatu usaha perusahaan dalam menyampaikan informasi, berkomunikasi, melakukan promosi, serta menjual produk dan jasa dengan menggunakan internet pemasaran dengan menggunakan basis digital atau elektronik berguna bagi perusahaan dapat memberikan informasi, melakukan komunikasi untuk ditawarkan melalui promosi dalam menjual produk dan jasa yang dibuat oleh perusahaan melalui internet (Kotler \& Keller, 2008).

Menurut Daryanto dalam (Arifin \& Fachrodji, 2015), promosi adalah arus informasi atau persuasi satu arah yang dapat mengarahkan organisasi atau seseorang untuk menciptakan transaksi antar pembeli dan penjual. Sedangkan menurut Widiyono Pakkanna (2013) mendefinisikan promosi adalah teknik atau berbagai cara yang dirancang untuk menjual produk atau pesan yang disampaikan perusahaan kepada konsumen tentang produknya. Efektifitas promosi, perusahaan yang memproduksi barang konsumsi biasanya menggunakan dana mereka untuk iklan. Iklan tersebut mengandung seperti halnya promosi penjualan, penjualan perorangan dan publisitas. Bauran promosi yang sangat dipengaruhi oleh pilihan perusahaan dan strategi mendorong atau strategi menarik untuk menjual produk (Irawan et al., 2001).

Definisi produk merupakan sebagai suatu yang dapat ditawarkan dan diperjualkan untuk kebutuhan. Fungsi produk untuk mendapatkan perhatian, dibeli, dipergunakan, atau dikonsumsi dan yang dapat memuaskan keinginan atau kebutuhan. Menurut (Nangoy et al., 2017) indikator promosi adalah promosi penjualan, periklanan, tenaga penjualan, kehumasan, pemasaran langsung. 


\subsection{Era Digitalisasi}

Menurut Memenemy \& Poutler dalam (Artitis, 2009), digitalisasi adalah menciptakan kopi digital dari sebuah objek analog yang dalam mendigitalkan sebuah dokumen, mempunyai banyak keuntungan dengan mudah diakses, dicari, maupun diindeks. Kelebihan digitalisasi adalah lebih tegas, informasi digital lebih mudah dikelola atau mudah disimpan dalam memori, mudah ditransmisikan, mudah dimunculkan kembali, dan mudah diolah tanpa adanya penurunan kualitas, lebih tahan terhadap gangguan (Sumarna, 2006).

Menurut Caleb T. Carr dan Rebecca A. Hayes dalam (Santoso, 2018) bahwa sosial media adalah media berbasis internet yang memungkinkan pengguna berkesempatan untuk berinteraksi dan mempresentasikan diri, baik secara seketika maupun tertunda dengan khalayak luas maupun tidak untuk berinteraksi dengan orang lain. Adanya sosial media bisa melakukan komunikasi atau berinteraksi, berkirim pesan, baik pesan teks, gambar, audio hingga video, saling berbagi atau sharing, dan juga membangun jaringan atau networking. Sosial media merupakan sebuah daring yang dapat meningkatkan pangsa pasar dalam suatu penjualan baik dalam bentuk produk dan jasa. Adanya sosial media setiap orang dapat saling terhubung antara satu dengan yang lainnya tanpa batasan jarak dan waktu sehingga memudahkan berinteraksi pembeli dengan penjual (Aklani, 2016).

\subsection{Minat Masyarakat Berumrah}

Menurut Andi Mappiare dalam (Saraswati, 2016), minat adalah suatu rangkaian keinginan yang terdiri dari suatu gabungan dari berbagai perasaan, harapan, pendirian, prasangka, rasa takut atau kecenderungan lainnya yang menjadikan individu tersebut untuk memilih suatu pilihan tertentu. Minat menurut merupakan suatu motivasi seseorang yang mendorong untuk melakukan apa yang mereka inginkan ketika mereka bebas memilih. Dengan demikian minat masyarakat adalah suatu dorongan atau keinginan seseorang atau sekelompok orang yang saling berinteraksi terhadap suatu objek tertentu (Wijayanti, 2014).

Ibadah umrah berarti berkunjung ke baitullah, melaksanakan thawaf dan sa'i dengan syarat dan waktu yang telah ditentukan. Umrah secara bahasa berarti berkunjung dan secara istilah ialah berkunjung ke baitullah dengan melaksanakan syarat yang telah ditetapkan dalam rangka mendekatkan diri kepada Allah SWT (Wijayanti, 2014). PPIU merupakan penyelenggara perjalanan ibadah umrah, penyelenggara perjalanan ibadah umrah harus memenuhi persyaratan sesuai yang terteta pada pasal 89 UU No. 8 Tahun 2019 (Djaman, 2019).

\subsection{Hipotesis}

Hipostesis merupakan jawaban sementara terhadap perumusan masalah penelitian, dimana rumusan masalah penelitian telah dinyatakan dalam bentuk kalimat pertanyaan (Sugiyono, 2015). Adapun penelitian terdahulu dari (Satria, 2017) menyatakan bahwa promosi berpengaruh signifikan terhadap minat beli konsumen. Penelitian dari (Lancarya, 2016),menyatakan bahwa promosi online berpengaruh positif 
terhadap keputusan pembelian. Dari penjelasan tersebut penulis merumuskan hipotesis sebagai berikut:

$\mathrm{H}_{1}$ : Diduga promosi produk era digital berpengaruh terhadap minat masyarakat untuk umrah di Biro Hajar Aswad Mubaroq Surakarta.

$\mathrm{H}_{\mathrm{o}} \quad$ : Diduga promosi produk era digitalisasi tidak berpengaruh terhadap minat masyarakat untuk umrah di Biro Hajar Aswad Mubaroq Surakarta.

\section{Metode Penelitian}

\subsection{Tahapan Penelitian}

Penelitian ini dilakukan pada bulan desember 2019 sampai agustus 2020. Fokus tempat penelitian yaitu di Biro Hajar Aswad Mubaroq Surakarta. Jenis penelitian ini yaitu penelitian kuantitatif. Penelitian kuantitatif digunakan dalam meneliti suatu populasi dan sampel tertentu, pengumpulan data yang menggunakan instrumen penelitian, analisis data yang bersifat kuantitatif atau statistik yang berfungsi menguji hipotesis yang sudah ditentukan (Sugiono, 2018).

\subsection{Populasi dan Sampel Penelitian}

Populasi adalah wilayah generaliasasi yang terdiri atas objek atau subjek yang mempunyai kualitas dan karakteristik tertentu yang ditetapkan oleh peneliti untuk diperoleh dan kemudian ditarik kesimpulannya (Sugiono, 2018). Populasi dalam penelitian ini adalah jamaah dari biro Hajar Aswad Mubaroq Surakarta yang berada di kota Surakarta yang sudah mendaftar dan berangkat dari periode 115 Januari 2020 sebanyak 167 orang. Teknik penarikan sampel dalam penelitian ini menggunakan rumus slovin dan diperoleh sebanyak 118 responden.

Teknik pengambilan sampel yang digunakan yaitu Non Probability Sampling. Lalu cara pengambilan sampel menggunakan teknik purposive sampling. Purposive sampling yaitu teknik penentuan sampel berdasarkan kebutuhan bila dianggap cocok sebagai sumber data atau dengan kata lain dengan adanya pertimbangan terlebih dahulu (Ahmad, 2009). Adapun karakteristik responden dalam penelitian ini yaitu:

a. Jamaah dengan minimal umur 17 tahun

b. Sudah pernah melihat promosi produk umrah pada whatsApp, instagram, facebook di Biro Hajar Aswad Mubaroq Surakarta.

\subsection{Teknik Pengumpulan Data dan Analisis} Data

Teknik pengumpulan data merupakan langkah yang amat penting diperoleh dalam metode ilmiah. Menurut Nazir, pengumpulan data adalah suatu tata cara yang sistematik dan standar digunakan untuk mendapatkan data yang diperlukan. Dalam penelitain ini metode pengumpulan data yang digunakan dengan menyebar kuesioner atau angket, angket atau kuesioner sering disebut dengan pengumpulan data yang menggunakan pertanyaanpertanyaan yang dijawab dan ditulis oleh responden (Ahmad, 2009).

Teknik analisis data yang digunakan dalam penelitian ini yaitu analisis statistik deskriptif, uji kuesioner, uji asumsi klasik, dan uji regresi linier sederhana. 


\section{Hasil dan Pembahasan}

\subsection{Gambaran Umum Obyek Penelitian}

Biro Hajar Aswad Mubaroq merupakan pelopor biro perjalanan umum berbasis Solo dan Semarang. Biro Hajar Aswad Mubaroq berdiri pada 17 Agustus 2012 yang menyediakan paket perjalanan umroh, haji plus, dan. Jamaah umroh Biro Hajar Aswad Mubaroq hingga febuari 2019 telah memberangkatkan kurang lebih 9000 jamaah ke tanah suci. Dipimpin oleh $\mathrm{Ibu} \mathrm{Hj}$. Retno Anugerah Andriyani dan adapun produk jasa umrah yang terdapat di Biro Hajar Aswad Mubaroq Surakarta antara lain, paket umrah januari ( paket ini menyesuaikan setiap bulannya ), paket umrah regular, paket umroh promo 3 gratis 1, paket umrah bersama hafidz terkenal, paket umrah special bintang lima, terdapat juga paket umrah di bulan ramdhan dan paket umrah sekaligus dengan liburan misalnya paket umrah + Turkey.

\subsection{Analisis Deskriptif Karakteristik Responden}

Tabel 2. Frekuensi Responden Berdasarkan Jenis Kelamin

\begin{tabular}{|c|c|c|c|c|c|}
\hline \multicolumn{2}{|c|}{ Jenis Kelamin } & \multirow{2}{*}{$\begin{array}{l}\text { Frequ } \\
\text { ency }\end{array}$} & \multirow{2}{*}{$\begin{array}{c}\text { Perce } \\
n t\end{array}$} & \multirow{2}{*}{$\begin{array}{c}\text { Valid } \\
\text { Percent }\end{array}$} & Cumul \\
\hline & & & & & $\begin{array}{c}\text { Percen } \\
t\end{array}$ \\
\hline \multirow[t]{3}{*}{ Valid } & $\begin{array}{l}\text { Perem } \\
\text { puan }\end{array}$ & 63 & 53.4 & 53.4 & 53.4 \\
\hline & $\begin{array}{l}\text { Laki- } \\
\text { Laki }\end{array}$ & 55 & 46.6 & 46.6 & 100.0 \\
\hline & Total & 118 & 100.0 & 100.0 & \\
\hline
\end{tabular}

Berdasarkan tabel 2 menunjukkan bahwa responden yang berjenis kelamin perempuan lebih banyak dari jenis kelamin lakilaki. Responden berjenis kelamin laki-laki sebanyak 55 orang atau sebesar 46,6\% , sedangkan perempuan sebanyak 63 orang atau sebesar 53,4\% Dapat diketahui mengenai jenis kelamin jamaah Biro Hajar Aswad Mubaroq Surakarta yang diambil dari total 118 responden.

Tabel 3. Frekuensi Responden Bedasarkan Usia

\begin{tabular}{|c|c|c|c|c|c|}
\hline \multicolumn{2}{|c|}{ KategoriUsia } & \multirow{2}{*}{$\begin{array}{c}\text { Freque } \\
\text { ncy }\end{array}$} & \multirow{2}{*}{$\begin{array}{c}\text { Percen } \\
t\end{array}$} & \multirow{2}{*}{$\begin{array}{c}\text { Valid } \\
\text { Percent }\end{array}$} & \multirow{2}{*}{$\begin{array}{c}\text { Cumulati } \\
\text { ve } \\
\text { Percent }\end{array}$} \\
\hline & & & & & \\
\hline \multirow{4}{*}{$\begin{array}{l}\text { Vali } \\
\text { d }\end{array}$} & $17-36$ & 25 & 21.2 & 21.2 & 21.2 \\
\hline & $37-56$ & 73 & 61.9 & 61.9 & 83.1 \\
\hline & $57-76$ & 20 & 16.9 & 16.9 & 100 \\
\hline & Total & 118 & 100 & 100 & \\
\hline
\end{tabular}

Berdasarkan tabel 3 menunjukkan bahwa menunjukkan hasil bahwa mengenai usia jamaah Biro Hajar Aswad Mubaroq Surakarta yang diambil sebagai responden dari 118 orang yang diteliti menunjukkan usia 37-56 tahun merupakan jumlah tertinggi yaitu sebanyak 73 orang atau sebesar $61,9 \%$ serta responden terendah yaitu usia 17-36 tahun sebanyak 25 orang atau sebesar $21,2 \%$. Hal ini menunjukkan bahwa responden terbanyak dalam penelitian ini didapat masyarakat merupakan golongan usia dewasa yang berusia antara 37-56 tahun dari jumlah total keseluruhan responden sebanyak 118 orang yang diteliti. 
Tabel 4. Frekuensi Responden Berdasarkan Pekerjaan

\begin{tabular}{|c|c|c|c|c|c|}
\hline \multicolumn{2}{|c|}{$\begin{array}{l}\text { Bidang } \\
\text { Pekerjaan }\end{array}$} & $\begin{array}{c}\text { Freque } \\
\text { ncy }\end{array}$ & Percent & $\begin{array}{c}\text { Valid } \\
\text { Percent }\end{array}$ & $\begin{array}{c}\text { Cumulati } \\
\text { ve Percent }\end{array}$ \\
\hline \multirow[t]{7}{*}{ Valid } & Swasta & 38 & 32.2 & 32.2 & 32.2 \\
\hline & $\begin{array}{l}\text { Wiraswa } \\
\text { sta }\end{array}$ & 20 & 16.9 & 16.9 & 49.2 \\
\hline & PNS & 14 & 11.9 & 11.9 & 61.0 \\
\hline & Petani & 12 & 10.2 & 10.2 & 71.2 \\
\hline & $\begin{array}{l}\text { Pedagan } \\
\text { g }\end{array}$ & 13 & 11.0 & 11.0 & 82.2 \\
\hline & IRT & 21 & 17.8 & 17.8 & 100 \\
\hline & Total & 118 & 100 & 100 & \\
\hline
\end{tabular}

Dari data tabel 4 di atas menunjukkan bahwa jamaah umrah Biro Hajar Aswad Mubaroq Surakarta yang diambil responden penelitian memiliki berbagai macam pekerjaan. Tabel di atas menjelaskan informasi bahwa responden dari jamaah Biro Hajar Aswad yang berprofesi sebagai pegawai swasta sebanyak 38 orang atau sebesar $32,2 \%$, responden yang bekerja sebagai pegawai wiraswasta sebanyak 20 orang atau sebesar $16,9 \%$, responden yang bekerja sebagai PNS (Pegawai Negeri Sipil) sebanyak 14 orang atau sebesar $11,9 \%$, responden yang bekerja sebagai petani berjumlah 12 orang atau sebesar 10,2\%, responden yang bekerja sebagai pedagang sebanyak 13 orang atau sebesar 11,0\%, dan responden yang berprofesi sebagai IRT (Ibu Rumah Tangga) sebanyak 21 orang atau sebesar $17,8 \%$.
Tabel 5. Frekuensi Responden Berdasarkan Sumber Promosi

\begin{tabular}{llrrrr}
\hline Sumber Promosi & Frequency & $\begin{array}{l}\text { Per } \\
\text { cent }\end{array}$ & $\begin{array}{c}\text { Valid } \\
\text { Percent }\end{array}$ & $\begin{array}{c}\text { Cumula } \\
\text { tive } \\
\text { Percent }\end{array}$ \\
\hline Val & & & & & Facebook \\
\cline { 2 - 6 } id & 39 & 33.1 & 33.1 & 33.1 \\
\cline { 2 - 6 } & Instagram & 13 & 11.0 & 11.0 & 44.1 \\
\cline { 2 - 6 } & WhatssApp & 66 & 55.9 & 55.9 & 100 \\
\cline { 2 - 6 } & Total & 118 & 100 & 100 & \\
\hline \multicolumn{5}{c}{ Sumber: Data Diolah, 2020 }
\end{tabular}

Dari data tabel 5 data di atas menunjukkan bahwa frekuensi responden jamaah Biro Hajar Aswad Mubaroq yang pernah menggunakan jasa untuk melaksanakan umroh mengetahui promosi produk jasa tersebut yang paling banyak pada whatssApp. Responden sebanyak 39 orang atau sebesar $33,1 \%$ pernah melihat promosi produk pada facebook, responden sebanyak 13 orang atau sebesar $11,0 \%$ pernah melihat promosi produk di instagram, dan responden sejumlah 66 orang atau sebesar $55,9 \%$ pernah melihat promosi produk pada whatssApp. Kesimpulan dari penjelasan tersebut menunjukkan bahwa promosi produk di era digitalisasi melalui media sosial yang dilakukan Biro Hajar Aswad menunjukkan angka tertinggi pada whatssApp. Hal ini menunjukkan bahwa aplikasi whatssApp sudah menjadi media komunikasi mudah digunakan oleh seluruh kalangan masyarakat di era digitalisasi ini. 


\subsection{Hasil Uji Kuesioner}

\subsubsection{Uji Validitas}

Uji validitas digunakan untuk mengukur sah atau valid tidaknya suatu kuesioner (Ghozali, 2016). Jika nilai $r$ hitung $>r$ tabel maka pertanyaan dinyatakan valid. Sedangkan jika sebaliknya nilai $r$ hitung $<\mathrm{r}$ tabel maka pertanyaan dinyatakan tidak valid. Pengujian validitas dilakukan pada dua variabel dalam penelitian ini yaitu, promosi produk dan minat masyarakat dengan didapat tabel sebesar 0,152. Hasil uji validitas dapat dijelaskan pada tabel sebagai berikut.

Tabel 6. Hasil Uji Validitas Variabel Promosi

\begin{tabular}{|c|c|c|c|c|}
\hline $\begin{array}{c}\text { Nilai } \\
\text { rhitung }\end{array}$ & $\begin{array}{l}\text { Nilai } \\
\text { rtabel }\end{array}$ & $\begin{array}{l}\text { Nilai } \\
\text { Sig.2- } \\
\text { Tailed }\end{array}$ & $\begin{array}{c}\text { Nilai } \\
\alpha=0,05\end{array}$ & Keputusan \\
\hline 0,411 & 0,152 & 0,000 & 0,05 & Valid \\
\hline 0,387 & 0,152 & 0,000 & 0,05 & Valid \\
\hline 0,585 & 0,152 & 0,000 & 0,05 & Valid \\
\hline 0,491 & 0,152 & 0,000 & 0,05 & Valid \\
\hline 0,669 & 0,152 & 0,000 & 0,05 & Valid \\
\hline 0,569 & 0,152 & 0,000 & 0,05 & Valid \\
\hline 0,575 & 0,152 & 0,000 & 0,05 & Valid \\
\hline 0,584 & 0,152 & 0,000 & 0,05 & Valid \\
\hline 0,491 & 0,152 & 0,000 & 0,05 & Valid \\
\hline 0,563 & 0,152 & 0,000 & 0,05 & Valid \\
\hline 0,711 & 0,152 & 0,000 & 0,05 & Valid \\
\hline 0,661 & 0,152 & 0,000 & 0,05 & Valid \\
\hline 0,611 & 0,152 & 0,000 & 0,05 & Valid \\
\hline 0,497 & 0,152 & 0,000 & 0,05 & Valid \\
\hline 0,405 & 0,152 & 0,000 & 0,05 & Valid \\
\hline
\end{tabular}

Sumber: IBM SPSS Statistic 22
Berdasarkan tabel 6 dapat menunjukkan bahwa 15 item pernyataan untuk variabel promosi produk di era digitalisasi memiliki status valid yaitu dengan hasil $r$ hitung $>r$ tabel dengan hasil ukur yang sesuai maka menghasilkan data yang relevan sesuai dengan tujuan pengukuran.

Tabel 7. Hasil Uji Validitas Variabel Minat

\begin{tabular}{ccccc}
\multicolumn{5}{c}{ Masyarakat } \\
\hline $\begin{array}{c}\text { Nilai } \\
\text { rhitung }\end{array}$ & Nilai & Nilai & Nilai & Keputusan \\
& & $\begin{array}{c}\text { Sig.2- } \\
\text { Tailed }\end{array}$ & $\boldsymbol{\alpha = 0 , 0 5}$ & \\
\hline 0,635 & 0,152 & 0,000 & 0,05 & Valid \\
\hline 0,515 & 0,152 & 0,000 & 0,05 & Valid \\
\hline 0,718 & 0,152 & 0,000 & 0,05 & Valid \\
\hline 0,668 & 0,152 & 0,000 & 0,05 & Valid \\
\hline 0,643 & 0,152 & 0,000 & 0,05 & Valid \\
\hline 0,639 & 0,152 & 0,000 & 0,05 & Valid \\
\hline 0,467 & 0,152 & 0,000 & 0,05 & Valid \\
\hline Sumber IBM SPSS Static 22 & &
\end{tabular}

Sumber: IBM SPSS Statistic 22

Berdasarkan hasil analisis dari uji validitas minat masyarakat $\mathrm{di}$ atas dapat diketahui bahwa dari 7 item pernyataan, dapat diketahui bahwa seluruh item pernyataan dinyatakan valid dengan nilai $r$ hitung $>r$ tabel dengan hasil ukur yang sesuai maka menghasilkan data yang relevan sesuai dengan tujuan pengukuran.

\subsubsection{Uji Reliabilitas}

Uji reliabilitas dilakukan untuk menguji konsistensi jawaban responden untuk menjawab pernyataan-pernyataan yang mengukur variabel promosi dan minat masyarakat Biro Hajar Aswad Mubaroq Surakarta. Uji reliabilitas dapat dilihat dari hasil output SPSS, uji reliabilitas 
kuesioner diperlihatkan oleh nilai Cronbach Alpha. Suatu variabel dikatakan reliabel jika memberikan nilai Cronbach Alpha> 0,70 (Ghozali, 2016).

Tabel 8. Hasil Uji Reliabilitas

\begin{tabular}{cccc}
\hline $\begin{array}{c}\text { Variabel } \\
\text { Penelitian }\end{array}$ & $\begin{array}{c}\text { Cronbach } \\
\text { Alpha }\end{array}$ & $\begin{array}{c}\text { Nilai } \\
\text { Kritis }\end{array}$ & Keterangan \\
\hline Promosi Produk & 0,836 & 0,7 & Reliabel \\
\hline $\begin{array}{c}\text { Minat } \\
\text { Masyarakat }\end{array}$ & 0,728 & 0,7 & Reliabel \\
\hline \multicolumn{2}{l}{ Sumber: IBM SPSS Statistic 22 } & &
\end{tabular}

Dari tabel 8 di atas, hasil uji reliabilitas instrument menunjukkan bahwa kedua variabel yaitu promosi produk era digitalisasi dan minat masyarakat dinyatakan reliabel karena nilai Cronbach Alpha> 0,70. Sehingga dapat disimpulkan bahwa semua variabel yang digunakan dalam penelitian ini berstatus reliabel. Selanjutnya dapat dipergunakan sebagai alat pengumpulan data penelitian.

\subsection{Uji Asumsi Klasik}

\subsubsection{Uji Normalitas}

Uji Normalitas data digunakan untuk mengetahui apakah data yang digunakan terdistribusi normal atau tidak. Model regresi yang baik adalah distribusi datanya normal atau mendekati normal. Untuk menguji normalitas dapat digunakan Kolmogrov-Seminorv Test.
Tabel 9. Hasil Uji Normalitas

\begin{tabular}{llr}
\hline & & $\begin{array}{r}\text { Unstandardi } \\
\text { zed Residual }\end{array}$ \\
\hline $\mathrm{N}$ & & 118 \\
\hline Normal Parameters $^{\mathrm{a}, \mathrm{b}}$ & Mean & .0000000 \\
\cline { 2 - 3 } & Std. & 1.98596387 \\
& Deviation & \\
\hline Most Extreme & Absolute & .063 \\
\cline { 2 - 3 } Differences & Positive & .050 \\
\cline { 2 - 3 } & Negative & -.063 \\
\hline Test Statistic & & .063 \\
\hline Asymp. Sig. (2-tailed) & & $.200^{\mathrm{c}, \mathrm{d}}$ \\
\hline \multicolumn{2}{c}{ Sumber : IBM SPSS Statistic 22 } &
\end{tabular}

Berdasarkan tabel di atas setelah dilakukan perhitungan diperoleh hasil nilai sig variabel menunjukkan angka 0,200 yang menunjukkan hasil tersebut lebih besar dari 0,05. Sehingga dapat disimpulkan bahwa data jawaban yang dinyatakan memenuhi asumsi normalitas atau distribusi data dalam penelitian normal.

\subsubsection{Uji Heteroskedastisitas}

Pengujian Heteroskedastisitas bertujuan untuk mengetahui apakah dalam sebuah model regresi terdapat ketidaksamaan varians dari residual antara satu pengamatan dengan pengamatan yang lain. Untuk mendeteksi adanya heteroskedastisitas dari tingkat signifikansi dapat digunakan Uji Glejser. Hasil uji heteroskedastisitas ditunjukkan pada tabel berikut ini: 
Tabel 10. Hasil Uji Heteroskedastisitas

\begin{tabular}{|c|c|c|c|c|c|}
\hline \multirow[b]{3}{*}{ Model } & \multicolumn{2}{|c|}{$\begin{array}{c}\text { Unstandardized } \\
\text { Coefficients }\end{array}$} & \multirow[t]{2}{*}{$\begin{array}{c}\text { Standardized } \\
\text { Coefficients }\end{array}$} & \multirow[b]{3}{*}{$\mathrm{T}$} & \multirow[b]{3}{*}{ Sig. } \\
\hline & & Std. & & & \\
\hline & $B$ & Error & Beta & & \\
\hline \multirow[t]{2}{*}{1 (Constant) } & 3,32 & & & & \\
\hline & 3 & 1,531 & & 2,171 &, 032 \\
\hline \multirow[t]{2}{*}{ PROMOSI } & - & ,024 &,- 110 & $-1,188$ & ,237 \\
\hline & ,028 & & & & \\
\hline
\end{tabular}

Sumber: Data diolah, 2020

Berdasarkan hasil pengujian tabel di atas, menunjukkan bahwa variabel lebih besar dari 0,05, sehingga dapat disimpulkan bahwa dalam model regresi tersebut tidak ada gejala heteroskedastisitas.

\subsection{Analisis Regresi Linier Sederhana}

\subsubsection{Uji T}

Uji T digunakan untuk mengetahui signifikansi pengaruh variabel-variabel independen $(\mathrm{X})$ terhadap variabel dependen $(\mathrm{Y})$ secara parsial. Besarnya nilai t hitung ini yang menentukan signifikan tidaknya variabel $\mathrm{X}$ dalam mempengaruhi variabel Y.

Tabel 11. Hasil Uji T

\begin{tabular}{|c|c|c|c|c|c|}
\hline \multirow[t]{2}{*}{ Model } & \multicolumn{2}{|c|}{$\begin{array}{c}\text { Unstandardized } \\
\text { Coefficients }\end{array}$} & \multirow{2}{*}{$\begin{array}{c}\text { Standardized } \\
\text { Coefficients }\end{array}$} & \multirow[t]{2}{*}{$T$} & \multirow[b]{2}{*}{ Sig. } \\
\hline & $B$ & Std. Error & & & \\
\hline (Constant & 1.756 & 2.387 & & .736 & .463 \\
\hline $\begin{array}{l}\text { Promosi } \\
\text { Produk }\end{array}$ & .421 & .037 & .726 & 11.363 & .000 \\
\hline
\end{tabular}

Dependent Variable: Minat Masyarakat

$\mathrm{T}$ tabel $=1,658$

$\mathrm{F}$ tabel $=3,92$

Sumber: Data diolah, 2020
Dari tabel tersebut adalah hasil perhitungan untuk variabel promosi produk memiliki nilai $\mathrm{t}$ hitung sebesar 11,363 > t tabel 1,658 dan nilai signifikansinya sebesar $0,000<$ 0,05 yang artinya variabel promosi produk di era digitalisasi signifikan terhadap minat masyarakat untuk umrah di Biro Hajar Aswad Mubaroq Surakarta atau dengan kata lain bahwa $\mathrm{H}_{1}$ Diterima.

\subsubsection{Uji F}

Uji F digunakan untuk mengetahui apakah variabel-variabel independen secara serentak atau bersama-sama dalam mempengaruhi variabel dependen. Atau dengan kata lain apakah ada pengaruh antara faktor promosi produk (variabel bebas) di era digitalisasi dengan minat masyarakat (variabel terikat) di Biro Hajar Aswad Mubaroq Surakarta. Daerah penolakan adalah ketika F hitung > F tabel. Adapun hasil uji $\mathrm{f}$ adalah sebagai berikut:

Tabel 12. Hasil Uji F

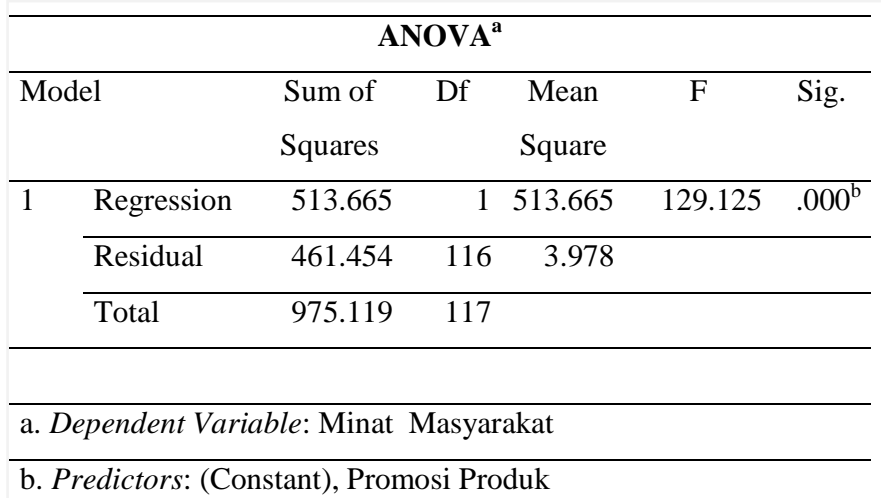

Sumber: Data diolah, 2020

Berdasarkan hasil analisis uji $\mathrm{f}$ yang dilakukan, diketahui f hitung sebesar 129,125 lebih besar dibandingkan dengan $\mathrm{f}$ tabel, maka 
$\mathrm{H}_{\mathrm{o}}$ ditolak dan secara langsung $\mathrm{H}_{1}$ diterima, sehingga variabel promosi produk berpengaruh secara signifikan terhadap minat masyarakat untuk umrah di Biro Hajar Aswad Mubaroq Surakarta.

\subsubsection{Koefisien Determinasi $\left(\mathbf{R}^{2}\right)$}

Koefisien determinasi digunakan untuk mengukur proporsi atau presentasi sumbangan dari variabel bebas $(\mathrm{X})$ yang terdapat dalam model regresi terhadap variabel terikat (Y). Koefisien determinasi dapat dilihat sebagai berikut:

Tabel 13. Hasil Uji Determinasi

\begin{tabular}{lcccr}
\hline \multicolumn{5}{c}{ Model Summary } \\
\hline Model & $\mathrm{R}$ & $R$ & Adjusted $R$ & Std. Error of \\
& & Square & Square & the Estimate \\
\hline 1 & $.726^{\mathrm{a}}$ & .527 & .523 & 1.99451 \\
\hline a. Predictors: (Constant), Promosi Produk \\
\hline
\end{tabular}

Sumber: Data diolah, 2020

Berdasarkan data di atas, hasil perhitungan untuk nilai $\mathrm{R}^{2}$ dengan bantuan $I B M$ SPSS Ststistics 22, dalam analisis regresi linier sederhana diperoleh angka koefisien determinasi atau $\mathrm{R}^{2}$ sebesar 0,527 . Hal tersebut berarti bahwa besarnya pengaruh promosi produk diera digitalisasi terhadap minat masyarakat untuk umrah di Biro Hajar Aswad Mubaroq Surakarta adalah sebesar $52,7 \%$.

\section{Pembahasan}

Pengunaan sosial media di era digitalisasi ini menjadi keunggulan tersendiri karena tentunya mudah diterima dan dilihat oleh sebagian besar masyarakat. Sebagian besar masyarakat sekarang sudah tidak asing akan mengenal media sosial mereka di kehidupan sehari-hari guna mencari informasi atau bertukar informasi. Dengan adanya proses pemasaran melalui media sosial di era digitalisasi ini sendiri akan snagat menguntungkan terutama pada bisnis umrah. Minat masyarakat akan lebih banyak dan tertarik jika mereka melihat langsung suatu produk atau jasa yang dipromosikan melalui media yang sering mereka gunakan ssbagai contohnya pada media sosial seperti whatssApp, instagram, dan facebook. Hal ini sesuai dengan salah satu pendapat yang mengungkapkan bahwa e-marketing suatu perusahaan dalam menyampaikan informasi, berkomunikasi, melakukan promosi serta menjual produk dan jasa dengan menggunakan internet akan mudah diterima dan berkembang pesat (Kotler \& Keller, 2008).

Berdasarkan hasil penelitian tentang "Pengaruh Promosi Produk Di Era Digitalisasi Terhadap Minat Masyarakat Untuk Umrah Di Biro Hajar Aswad Mubaroq Surakarta”. Diperoleh hasil sebagai berikut:

$\mathrm{H}_{1}$ : Promosi produk era digitalisasi berpengaruh signifikan terhadap minat masyarakat.

Berdasarkan hasil perhitungan analisis regresi diketahui variabel promosi produk memiliki nilai t hitung sebesar 11,363 > t tabel 1,658 dan nilai signifikansi sebesar $0,000<0,05$ maka yang berarti $\mathrm{H}_{0}$ ditolak dan $\mathrm{H}_{1}$ diterima. Sehingga dapat disimpulkan artinya bahwa 
variabel promosi produk di era digitalisasi berpengaruh signifikan terhadap minat masyarakat untuk umrah di Biro Hajar Aswad Mubaroq Surakarta.

Hasil tersebut juga sesuai dengan penelitian dari (Lancarya, 2016) yang menyatakan bahwa adanya promosi yang dilakukan secara online konsumen mendapatkan kemudahan dalam dalam meperoleh informasi yang terkait dengan produk jasa dari Sun Travel, akibat adanya promosi secara online Sun Travel mengalami peningkatan jumlah konsumen dibandingkan dengan saat promosi dilakukan secara tradisional. Dalam penelitian lain dikemukakan bahwa promosi online dan persepsi harga secara bersama berpengaruh signifikan terhadap keputusan pembelian pada suatu perusahaan tersebut (Jamaludin, Arifin, \& Hidayat, 2015). Dengan adanya implementasi bauran promosi yang dilakukan dalam sebuah perusahaan melalui periklanan menggunakan media surat kabar, internet, dapat mempengaruhi peningkatan jumlah jamaah umrah (Tasya, 2016).

Hal ini sesuai dengan teori dari Kotler dan Keller yang mengatakan bahwa salah satu bentuk pemasaran saat ini yang menunjukkan perkembangan sangat pesat yaitu $e$ - marketing ( electronic marketing ) (Kotler \& Keller, 2012). Promosi produk di era digitalisasi berpengaruh positif terhadap minat masyarakat untuk umrah karena dengan adanya promosi produk yang dilakukan mengikuti perkembangan yang sedang pesat akan berpengaruh signifikan terhadap suatu perusahaan tersebut.

\section{Simpulan dan Saran}

\subsection{Simpulan}

Promosi produk di era digitalisasi berpengaruh signifikan terhadap minat masyarakat untuk umrah di Biro Hajar Aswad Mubaroq Surakarta, dapat dilihat dari hasil analisis yang menunjukkan nilai t hitung sebesar 11,363 dan $\mathrm{t}$ tabel sebesar 1,658 jadi t hitung lebih besar dari $\mathrm{t}$ tabel ( $\mathrm{t}$ hitung > $\mathrm{t}$ tabel). Hal ini berarti $\mathrm{H}_{\mathrm{o}}$ ditolak dan $\mathrm{H}_{1}$ diterima, sehingga variabel promosi produk berpengaruh positif terhadap minat masyarakat.

$$
\text { Variabel } \mathrm{x} \quad \text { (promosi produk) }
$$
mempengaruhi variabel y (minat masyarakat). Hubungan antara promosi produk di era digitalisasi dan minat masyarakat dimana promosi produk dapat mempengaruhi minat masyarakat dan sebaliknya. Adanya promosi produk mendatangkan keuntungan dimana minat masyarakat akan dipengaruhi oleh promosi produk di era digitaliasasi.

\subsection{Saran}

Berdasarkan simpulan di atas maka saran dalam penelitian ini adalah sebagai berikut:

1. Perlunya memperluas kajian dengan menambah variabel dan faktor lain dengan analisis pembahasan yang lebih matang.

2. Biro Hajar Aswad Mubaroq Surakarta diharapkan mampu mempertahankan dan meningkatkan kreatifitas serta inovasi 
untuk promosi khususnya di media sosial, sehingga mampu meningkatkan jumlah jamaah umrah dan menarik minat masyarakat untuk melaksanakan umrah.

\section{Daftar Pustaka}

Ahmad, T. (2009). Pengantar Metode Penelitian (N. Ngainun, Ed.). Yogyakarta: Teras.

Aklani, S. A. (2016). Pemanfaatan Sosial Media Sebagai Media Promosi Mahasiswa Pada Matakuliah Kewirausahaan di Universitas Internasional Batam. 23-24.

Arifin, E., \& Fachrodji, A. (2015). Pengaruh Persepsi Kualitas Produk, Citra Merek Dan Promosi Terhadap Minat Beli Konsumen Ban Achilles Di Jakarta Selatan. MIX, $V(1), 124-143$.

Artitis, U. (2009). Proyek Digitalisasi Naskah dan Skripsi Perpustakaan Fakultas Ilmu Pengetahuan Budaya Universitas Indonesia: Sebuah Evaluasi Perencanaan dan Pelaksanaan. Universitas Indonesia.

Djaman, L. S. (2019). UU No 8 Tahun 2019. (004251).

Fajar. (2019). Wawancara promosi produk era digital. Surakarta.

Ghozali, I. (2016). Aplikasi Analisis Multivariete (8th ed.). Semarang: Badan PenerbitUndip.

Gunaryo, A. (2018). PMA NO 8 TAHUN 2018.
$1-26$.

Irawan, Wijaya, F., \& Sudjoni. (2001). Pemasaran Prinsip dan Kasus. Yogyakarta.

Jamaludin, A., Arifin, Z., \& Hidayat, K. (2015). Pengaruh Promosi Online Dan Persepsi Harga Terhadap Keputusan Pembelian ( Survei Pada Pelanggan Aryka Shop di Kota Malang ). Administrasi Bisnis, 21(1).

Kotler, P., \& Armstrong, G. (2012). Principles Of Marketing. New Jersey: Prentice-Hall.

Kotler, P., \& Keller, K. L. (2008). Manajemen Pemasaran. Indonesia: PT Indeks.

Kotler, P., \& Keller, K. L. (2012). Marketing Management. New Jersey: Pearson Education.

Lamazido, M. azi. (2016). Strategi Promosi Jasa Perjalanan Haji Dan Umrah Melalui Media Website. UIN Walisongo Semarang.

Lancarya, P. (2016). Pengaruh Promosi Online Terhadap Keputusan Pembelian. Universitas Muhammadiyah Purworejo.

Lynna. (2019). Mengulas Trend Digital Marketing Tahun 2019. Retrieved from https://www.kompasiana.com/lynna123/5e 0b087e097f3675ff2ebc52/mengulas-trenddigital-marketing-tahun-2019

Nangoy, S., Mandey, S. L., \& Kawet, L. (2017). Pengaruh Promosi, Harga, Dan Distribusi Terhadap Keputusan Pembelian Pakaian 
Pada Matahari Departemen Store Manado (Studi Kasus Di Matahari Departemen Store Manado Town Scuare). Jurnal Ilmiah Society, 456頁、453頁、603頁.

Safira, N. P. (2018). Pemanfaatan Media Sosial sebagai Media Promosi Baru dalam Usaha Kuliner. Retrieved from https://www.kompasiana.com/putrynadiasa fira3957/5b4df89f6ddcae2eb669c112/medi a-sosial-sebagai-media-promosi-barudalam-usaha-kuliner?page $=2$

Santoso, P. Y. (2018). Transformasi Integrated Marketing Communication Di Era Digital. Jurnal Pustaka Komunikasi, 1, 313-326.

Saraswati, N. (2016). Pengaruh Pengetahuan Masyarakat Terhadap Minat Menjadi Nasabah Bank Muamalat KCP Magelang. UIN Walisongo.

Satria, A. A. (2017). Pengaruh Harga, Promosi, Dan Kualitas Produk Terhadap Minat Beli Konsumen Pada Perusahaan A-36. 2(April).

Sholihin, M. R., Arianto, W., \& Khasanah, D. F. (2018). Keunggulan Sosial Media Dalam Perkembangan Ekonomi Kreatif Era Dugital Di Indonesia.

Sugiono, D. (2018). Metode Penelitian. Bandung: Alfabeta.

Sugiyono. (2015). Metode Penelitian Pendidikan. Bandung: Alfabeta.
Sumarna. (2006). Elektronika Digital. Yogyakarta: Graha Ilmu.

Tasya, F. (2016). Implementasi Bauran Promosi Dalam Meningkatkan Jumlah Jamaah Umroh Pada PT. Al-Amin Universal Jakarta. UIN Syarif Hidayatullah Jakarta.

Wijayanti, I. T. (2014). Pengaruh Minat Masyarakat Memilih Biro Perjalanan Umroh Disaat Maraknya Kasus Penipuan Berkedok Umroh. Universitas Muhammadiyah Sidoarjo. 
Halaman ini sengaja dikosongkan untuk keperluan tata letak

Orasi: Jurnal Dakwah dan Komunikasi | Volume 12, No. 1, Juli 2021 